\title{
Modern Resource-Based Theory(ies)
}

\author{
Foss, Nicolai J.; Stieglitz, Nils
}

Document Version

Final published version

Publication date:

2010

\section{License \\ CC BY-NC-ND}

Citation for published version (APA):

Foss, N. J., \& Stieglitz, N. (2010). Modern Resource-Based Theory(ies). Institut for Strategic Management and Globalization. SMG Working Paper No. 7/2010

Link to publication in CBS Research Portal

\section{General rights}

Copyright and moral rights for the publications made accessible in the public portal are retained by the authors and/or other copyright owners and it is a condition of accessing publications that users recognise and abide by the legal requirements associated with these rights.

\section{Take down policy}

If you believe that this document breaches copyright please contact us (research.lib@cbs.dk) providing details, and we will remove access to the work immediately and investigate your claim. 
Modern Resource-Based Theory(ies)

Nicolai J. Foss

Nils Stieglitz

SMG WP 7/2010

September, 2010 
SMG Working Paper No. 7/2010

September, 2010

ISBN: 978-87-91815-60-7

Center for Strategic Management and Globalization Copenhagen Business School

Porcelænshaven 24

2000 Frederiksberg

Denmark

www.cbs.dk/smg 


\title{
MODERN RESOURCE-BASED THEORY(IES)
}

\author{
Nicolai J Foss \\ Center for Strategic Management and Globalization \\ Copenhagen Business School \\ Porcelainshaven 24B; 2000 Frederiksberg; Denmark \\ Njf.smg@cbs.dk \\ Nils Stieglitz \\ Strategic Organization Design Unit \\ Southern Denmark University \\ Campusvej 55; 5230 Odense; Denmark \\ nst@sam.sdu.dk \\ Prepared for Michael Dietrich and Jackie Krafft (eds), \\ Handbook on the Economics and Theory of the Firm, Edward Elgar, 2011.
}

September 7th, 2010

Keywords: Competitive advantage, firm-level heterogeneity, resources

JEL Coding: D21, D23, D83, L25 


\title{
MODERN RESOURCE-BASED THEORY(IES)
}

\begin{abstract}
We survey the resource-based view in strategic management, focusing on its roots in economics. We organize our discussion in terms of the Gavetti and Levinthal distinction between a "high church" and a "low church" resource-based view, and argue that these hitherto rather separate streams are increasingly overlapping.
\end{abstract}




\section{INTRODUCTION}

Almost since its inception, strategic management has been heavily indebted to economics, particularly mainstream economics (Porter, 1981; Rumelt, Schendel \& Teece, 1991; Camerer, 1994; Hoskission, Hitt, Wan \& Yiu, 1999; Foss, 2000; Lockett \& Thompson, 2001; Gavetti \& Levinthal 2004; Agarwal \& Hoetker, 2007). This is hardly surprising: Central, arguably the central, constructs of strategic management—namely, value creation, value appropriation and sustained competitive advantage-lend themselves directly to an economics interpretation. The notion that all of strategic management ultimately boils down to creating and appropriating more value than the competition (e.g., Peteraf \& Barney, 2003) can be usefully addressed in terms of the established economics corpus of applied price theory, industrial organization theory, game theory, and bargaining theory. Not surprisingly, modern strategic management theory is often presented as beginning from some “competitive imperfection” (Knott, 2003): ultimately, some deviation from the Walrasian general equilibrium model, or, in some formulations, from the zero transaction cost setting of the Coase theorem (Foss \& Foss, 2005), leading to imperfect factor and/or product markets, explain strategy’s central dependent variable, sustained competitive advantage. As Knott (2003: 929) argues, “[t]he field of strategy is concerned with the conditions under which the microeconomic equilibrium of homogenous firms with zero profits can be overcome.”

All modern economics-based approaches have taken this approach, beginning with Michael Porter's (1980, 1985) work, essentially an application of the industrial organization economics of Bain (1956) and Scherer (1980) (cf. Porter, 1981). Later currents in industrial organization, such as contestable markets theory (Baumol, Panzar \& Willig, 1982), game theoretical new industrial organization (Tirole, 1989), and the Chicago-UCLA approach (Demsetz, 1973) have also had enormous influence on strategic management. More specifically, contestable markets theory and new industrial organization have dominated the commitment approach (Ghemawat, 1991), and the 
Chicago-UCLA approach to industrial organization as well as ideas from Penrose (1959) and Schumpeter (1911) have motivated the resource-based view (Lippman \& Rumelt, 1982; Rumelt, 1984; Barney, 1986, 1991; Peteraf, 1993; Foss, 2000) — the key focus of the present chapter.

From the perspective of economics, the RBV is in many ways a half-way house. On the one hand, it revitalized the concern with firm heterogeneity, innovation, and dynamics associated with such heterodox economists as Thorstein Veblen (Foss, 1998), Joseph Schumpeter (1911), Edith Penrose (1959), and George Richardson (1972) (Jacobsson, 1992). On the other hand, what is perhaps the RBV core model (Demsetz, 1973; Lippman \& Rumelt, 1982; Barney, 1986, 1991; Peteraf, 1993; Peteraf \& Barney, 2003) is essentially a competitive equilibrium model with (at least one) heterogeneous firms. This tension has been manifest in the RBV from its inception in the beginning of the 1980s, and has led commentators to speak of "Demsetzian" and "Penrosian" (Foss, 2000) or "high-church" and "low-church" versions of the RBV (Gavetti and Levinthal, 2004) (cf. also Matthews, 2006, 2010; ). These distinctions boil down to the same thing: Is use made in the relevant RBV contribution of an equilibrium model with underlying strong assumptions of rationality, or does a process model with underlying behavioural assumptions closer to bounded rationality underpin the contribution? The high church $\mathrm{RBV}$, or the "RBV proper," is perhaps best associated with the VRIN framework of Barney (1991) (we discuss this later), while the low church RBV may be associated with ideas on core competences (Prahalad \& Hamel, 1990), capabilities (Winter, Denrell \& Fang, 2003) or dynamic capabilities (Teece, Pisano \& Shuen, 1997).

In this chapter we also adopt this distinction and use to organize our presentation and discussion of the RBV. However, as we point out the high and the low churches within the RBV make frequent contact, and, consistent with Gavetti and Levinthal's overall argument that the strategy field as a whole is manifesting a "movement toward the middle” (2004: 1312) there are signs of an emerging synthesis of the two. 


\section{ORIGINS AND KEY TENETS OF THE “HIGH CHURCH” RESOURCE-BASED VIEW}

\section{Origins}

The dominant contemporary approach in strategic management is the RBV, whether in its high or low church versions (Newbert, 2007; Acedo, Barroso, \& Galan, 2006; Heimeriks, Felin, Foss \& Zollo, 2010). Although part of the marketing effort of the RBV has been to point to its roots in Edith Penrose’s thinking on firm growth (Penrose, 1959; Kor \& Mahoney, 2000), the RBV does not get established in the strategy field until the seminal contributions by Lippman and Rumelt (1982), Wernerfelt (1984), Rumelt (1984) and Barney (1986). As already mentioned, resourcebased scholars have relied heavily on fundamental insights and theories of various fields and branches in economics, such as the economic theory of the entrepreneur (Barney, 1986; Knight, 1921; Rumelt, 1987); efficient markets theory (Barney, 1986; Fama, 1970); theories of input heterogeneity and its consequences for firm growth (Penrose, 1959; Wernerfelt, 1984); property rights economics (Coase, 1960; Teece, 1986; Kim \& Mahoney, 2005; Foss \& Foss, 2005); the theory of competitive equilibrium (Debreu, 1959; Lippman \& Rumelt, 1982); and, arguably, particularly Chicago-UCLA industrial organization economics (Demsetz, 1973, 1974; Peltzman, 1977; Klein; Crawford \& Alchian, 1978). Thus, the base of economics from which the RBV has drawn nourishment is one of applied micro-economics and efficient markets theory.

Chicago industrial economics as the foundation for the High Church RBV. Applied micro-economics and efficient markets theory are, of course, equilibrium theories. Not surprisingly, conomic equilibrium, particularly in the form of competitive equilibrium, is central in the high church RBV. Indeed, the dominance of the RBV has meant that the key issue of strategic management is routinely defined as the problem of achieving sustained competitive advantage in the sense of earning (efficiency) rents in equilibrium. The intellectual pedigree of this lies in the Chicago approach to industrial organization (Brozen, 1971; Demsetz, 1973, 1982, Peltzman, 1977). 
Briefly, a central aim of this approach is to explain long-lived performance differences in terms of efficiency rents existing under competitive conditions rather than in terms of monopolistic abuse of market power. In the Chicago view, entry barriers are informational, concentration is a result of efficiency, and high returns are returns to efficient underlying assets rather than monopoly profits stemming from restriction of supply (e.g., Demsetz 1973, 1982). Such returns may be long-lived because of the complexity of the assets that cause them (Demsetz 1973). Moreover, assets are not necessarily priced according to their value, because of informational asymmetries (idem.). Thus, the Chicago view of is one that stresses efficiency in a world constrained by informational scarcity. The appeal of the Chicago approach it that it promises to reconcile the emphasis on idiosyncratic and firm specific factors that is characteristic of the strategic management field with economic equilibrium theory. As we shall see, many of these key ideas have been taken over lock, stock and barrel by the High Church RBV. ${ }^{1}$

\section{Key Tenets}

The RBV is often presented as a "theory of the firm." Given the now dominant Coasian conception of what such a theory entails (Coase, 1937; Williamson, 1996), it is more correct to say that the RBV is first and foremost a theory of (firm-level) sustained competitive advantage that makes ample use of price theory. Sustained competitive advantage refers to the potential of a firm to create and appropriate more value than the competition (in some formulations, simply more than the marginal firm, e.g., Peteraf \& Barney, 2003), that is, the ability to capture a large share of the sum of producers and consumers surpluses than other firms (in the same industry). Thus, sustained competitive advantage is an antecedent to financial performance, not the same thing. In turn, this potential is traced to the resource endowments of firms and the characteristics of these resources. The crowning achievement of the high church RBV—and its main predictive context—has been the

\footnotetext{
${ }^{1}$ The Chicago legacy is perhaps most clearly present in an often cited paper by Peteraf (1993), which explicitly casts the RBV in terms of rents in competitive equilibrium, using the basic demand and supply apparatus of economics textbooks to graphically illustrate this.
} 
formulation of criteria that must be jointly met for resources to give rise to sustained competitive advantage (Barney, 1991; Peteraf \& Barney, 2003; Peteraf, 1993).

Thus, in Barney’s seminal 1991 paper, one of the most cited strategic management texts ever, and among a handful of social science papers with more than 10,000 Google scholar hits, sustained competitive advantage can be enjoyed by firms that control resources that are valuable, rare, and costly to imitate and substitute (i.e., the "VRIN framework”). He (1991: 102) explains that

A firm is said to have a competitive advantage when it is implementing a value creating strategy not simultaneously being implemented by any current or potential competitors. A firm is said to have a sustained competitive advantage when it is implementing a value creating strategy not simultaneously being implemented by any current or potential competitors and when these other firms are unable to duplicate the benefits of this strategy.

Thus, sustained competitive advantage is defined in terms of situations in which all attempts by competitor firms at imitating or substituting a successful firm have ceased, that is, equilibrium obtains. $^{2}$

Barney (1991) is not entirely forthcoming about the precise meaning of these criteria (Foss \& Knudsen, 2003), but value may be linked to the existence of a span between the reservation price of the products made possible by the relevant resource and the costs of production of those products; rare should be understood in a simple counting sense (implying that not "too many" other firms can

\footnotetext{
${ }^{2}$ In terms of the earlier point about the debt that the RBV owe to the Chicago-UCLA industrial economics tradition, Barney's analysis of the conditions under which such situations obtain is entirely in line with the Chicago school in its emphasis on resources (i.e., input factors) being costly to copy, etc. (compare Brozen, 1971; Demsetz, 1973, 1974, 1982, 1989; Peltzman, 1977). His argument that all performance differences are explainable in terms of differential efficiencies of the resources that underlie the strategies, and that, therefore, superior returns are fully compatible with social welfare, is straight out of the Chicago book (e.g., Demsetz 1974, 1989). Barney's (1986) earlier emphasis on factor market rather than product market imperfections as a condition of competitive advantage is also vintage Chicago (e.g., Demsetz, 1973).
} 
implement the same strategy(ies) as the firm enjoying a sustained competitive advantage), and the two remaining criteria refer to the costliness of imitating or substituting the resource or bundle of resources that give rise to the competitive advantage).

Earlier work by Barney (1986) established the necessary condition for sustained competitive advantage that the relevant underlying resources or the services thereof are acquired or rented at a price that is lower than their net present value. Otherwise, any competitive advantages will be offset by supply prices on “strategic factor markets.” This is explicitly included in Peteraf's (1993) closely related contribution, which also introduces a condition of relative immobility of resources: essential but highly mobile resources can appropriate most or all of the value they contribute to the firm.

\section{Empirical Work}

Despite its broad theoretical appeal and strong influence on managerial education and practice, the empirical track record of the key tenets of the RBV has so far been rather modest (Priem \& Butler 2001). Hoopes and Madsen (2008) argue that the RBV lacks a cumulative body of work showing how firms differ in their resource bases. In survey articles on the empirical support for the RBV, Armstrong and Shimizu (2007) and Newbert (2007) find only modest support for the key tenets of the RBV that connect resource characteristics to sustained profitability (cf. Crook et al. 2008 for a meta study that finds more robust support). Arend (2006: pp) even argue that ... there are no satisfactory empirical tests of the RBV. No paper or collection of related papers measures the benefits specified by RBV theory; adjusts for the costs of the resources; provides evidence that resources meet the RBV criteria; and controls for the influence of higher-level resources. Moreover, the adequacy of testing has not improved over the last 10 years. If empirical testing does not alter its approach, the RBV will be in increasing jeopardy. 
More broadly, Arend also argues that resources that meet the VRIO criteria are usually identified only ex post, making the explanation circular (empirical tests handle this problem, however); (2) the $\mathrm{RBV}$ is mainly used as a convenient framing device and specific implications of the view are seldom tested; (3) the link between resources and performance is not carefully examined, for example, in terms of organizational variables that mediate this link; (4) key resources are hard to measure, particularly those "socially complex" and "tacit” resources that the view often focuses on (e.g., Dierickx \& Cool, 1989; Barney, 1991); and (5) the gains from superior resources may not be captured at the firm level—but rather be captured by individual resources (Coff, 1997, 1999; Lippman \& Rumelt, 2003a)—in which case firm performance cannot be the dependent variable.

\section{Later Work}

Much subsequent research has consisted in elaborating, refining, extending and testing the core ideas of the RBV as well as refining the more specific criteria for sustained competitive advantage. We here briefly survey this work.

Resource accumulation. A central question in the RBV is what factors make resources hard to imitate. The seminal contribution here is the resource accumulation model advanced by Dierickx and Cool (1989) that was highly influential for subsequent work. Dierickx and Cool (1989) argue that competitive advantages stem from firm-specific resource stocks that need to be accumulated internally. Strategists are mainly concerned with the building of valuable stocks of resources (like brand reputation, manufacturing capabilities, technological expertise) by making appropriate choices about strategic investments flows. The imitability and sustainability of competitive positions result from the characteristics of the mapping of investment flows onto resource stocks. Dierickx and Cool argue that time compression diseconomies explain early-mover advantages, since higher investment outlays over a shorter period of time by a follower are required to catch up with an early-mover. Asset mass efficiencies confer an advantage to a firm that has already 
accumulated a critical mass of a resource (cf. Cohen \& Levinthal 1990). However, in the presence of asset erosion, Knott et al. (2000) argue and show empirically that time compression diseconomies and asset mass efficiencies are not sufficient to gain sustainable competitive advantages.

Rather, the interconnectedness of asset stocks and causal ambiguity appear to be necessary to explain long-term differences in resource stocks (Lippman \& Rumelt 1982; Barney 1991). The interconnectedness of asset stocks relate to complementarities among two or more resources (Stieglitz \& Heine 2007). The value of an asset stock depends on the presence of complementary resources, sharply increasing the investment costs for an imitator (Ghemawat 1991). Causal ambiguity obfuscates the link between resources and firm performance. It points to the tacitness, complexity, and specificity of the resource base (Reed \& DeFillippi 1990). Recent work has particularly highlighted the complexity of a firm's resource base as an effective barrier to imitation (Winter 2000; Rivkin 2000; Rivkin 2001). However, causal ambiguity of its resources may also restrict the strategic options of a firm, since it may find it impossible to transfer or to replicate the competitive advantage in a different context (Szulanski \& Winter 2001; King \& Zeithamel 2001). These characteristics also impact the tradability of resources. Thus, while generic resource may be acquired in factor markets, the firm-specific and idiosyncratic resources underpinning competitive advantages result from internal accumulation processes. Lippman and Rumelt (2003: 1082) succinctly summarize RBV's insistence on the primacy of internal resource accumulation: “The resource-based view predicts that firms will focus their energies on the development of complex ‘home-grown’ resources, taking time and care to develop knowledge, know-how, social capital, and other socially complex, difficult-to-transfer resources.” However, Makadok (2001) argues that resource development may not constitute the only causal mechanism to explain competitive advantages. Firms may also be better than others at picking undervalued resources in the market for 
resources. Resource-picking points to the role of strategic factor markets in explaining firm behavior and competitive advantage.

Strategic factor markets. Barney (1986) characterized markets for resources as strategic factor markets. Apart from luck, firms may only acquire resources below their net present value by forming heterogeneous expectations about resource value. Otherwise, prospective buyers bid up the price to the resource's net present value and the seller appropriates the value from the resource (e.g., Capron \& Shen, 2007). Much subsequent research on strategic factor markets has focused on the origins of differential expectations about resources. Chi (1994), Makadok (2001) and Makadok and Barney (2001) analyze differences in the information acquisition strategies of firms, while Denrell, Fang and Winter (2003) point to entrepreneurial serendipity to explain the acquisition of undervalued resources. A second line of inquiry has focused on co-specialization among heterogeneous resources (Teece 1986; Lippman \& Rumelt 2003; Adegbesan 2009). Even with perfect information, heterogeneous firms may place differential values on a complementary resource in a strategic factor market. With resource heterogeneity among buyers, gains from resource trade are not dissipated in a competitive bidding process and at least some of the resource value is appropriated by the buyer.

One of the traditional differentiating characteristics of the RBV is its focus on factor markets - to the exclusion of a concern with product markets. RBV scholars sometimes explain this as a simple intellectual division of labor, the positioning approach handling product imperfections (e.g., Porter, 1980), the RBV handling factor market imperfections (e.g., Barney, 1991). Accordingly, product markets are often treated as perfectly competitive in the RBV (e.g., Lippman \& Rumelt, 1982; Peteraf, 1993). However, it seems fundamentally odd for reasons of basic symmetry to invoke highly imperfect factor markets and perfect products at the same time, particularly given that one firm’s product market is another firm’s factor market (Foss \& Hallberg, 
2010). Priem and Butler (2001) argued that there are demand-side aspects of value creation that the RBV abstracts from. Thus, for any transaction, created value is the difference between the reservation price and the underlying costs of production. To the extent that the RBV essentially abstracts from the demand side by only focusing on competitive product markets, it also neglects an important part of value creation, as well as those resources (e.g., advertising capabilities) that are valuable because they can influence demand-side value creation.

Moreover, if product market conditions (i.e., what game forms characterize interaction in product markets) significantly influence factor market behaviors, it would seem odd to separate factor and product markets. In fact, recent work shows that there are close connections between product market and factor market behaviors (Asmussen, 2010; Makadok, 2010), which suggests that focusing on only upstream or downstream markets may lead analysis astray.

Work on strategic factor markets point to the more general problem of bargaining and rentsharing among resource owners (Peteraf 1993) (although small numbers bargaining on strategic factor markets still have to be modeled in the literature). Bargaining among resource owners has attracted a great deal of attention in recent contributions to the RBV.

Bargaining. Coff $(1997,1999)$ argues that rent-sharing and value appropriation among resource owners (e.g. employees, shareholders, suppliers) fundamentally depends on the bargaining power of each resource owner. Following in the tradition of Peteraf (1993), he shows how various instantiations of constrained resource mobility systematically influence the bargaining position of resource owners (cf. Jacobides, Knudsen \& Augier 2006). Lippman and Rumelt (2003a) and Adgbesan (2009), drawing on cooperative game theory, analyze how co-specialization among resources systematically change the outside options for resource owners and thereby determines their relative bargaining positions. Ryall and MacDonald (2004) add to this emerging stream of literature by establishing the necessary conditions for value appropriation. They highlight the 
importance of competition for a scarce resource among different resource coalitions for value appropriation. Blyler and Coff (2003) add a social dimension to the bargaining problem by stressing the role of social capital for attaining and leveraging bargaining power. However, recent research has also begun to point to the dynamic properties of bargaining power. That is, expectations about value appropriation drive investments into resources (Stieglitz \& Heine 2007) as well as the entrepreneurial search for new resource combinations (Lippman \& Rumelt 2003, Stieglitz \& Foss 2009). Explicit bargaining costs have yet to be considered within the RBV, however. Such costs is a part of the broader category of transaction costs.

Transaction Costs and property rights. Some proponents of the RBV have tried to separate it from the more mainstream economics of the firm (e.g., Conner, 1991; Conner \& Prahalad, 1996), and have argued that the RBV has the potential to develop into a distinct theory of the firm. It has become increasingly clear, however, that not only are the RBV and mainstream economics insights in transaction costs and property and how these shape economic organization highly complementary, there is also a very significant overlap (Foss, 1996; Silverman, 1999; Nickerson \& Zenger, 2004; Argyres \& Zenger, 2010). More generally, it is arguable that the RBV relies on competitive imperfections that are essentially in the nature of transaction costs or at least information costs, notably costs of imitation (Mahoney, 2001; Foss, 2003).

Foss and Foss (2005) argue that transaction costs are present right at the heart of the RBV. Thus, the basic unit of analysis in the RBV is the discrete resource. The notion of resource has a direct intuitive appeal because it can be so associated with real entities, like machines, buildings, experts, and so on. However, what firms ultimately demand are the services that resources yield (Penrose, 1959). In fact, resources are really collections of "attributes," that is, services, functionalities, etc. In a world without transaction costs, all these attributes could be identified and traded, and there would be no reason to trade discrete resources. To the extent that such resources 
are actually traded, it is because it pays in terms of transaction costs to bundle attributes in resources. The other side of the coin is that resources are really endogenous results of economizing with transaction costs. Relatedly, resource value is intimately related to transaction costs. Thus, the lower the costs of defining and enforcing property and ownership rights to resources, the higher the value of the relevant resource (all else equal) (Kim \& Mahoney, 2002; Foss \& Foss, 2005). Finally, some resources are valuable because they are capable of reducing transaction costs. Contracts, credit rating systems, organizational structures and so on may be analyzed in this light.

Path-dependent theoretical development. As the above brief review of RBV work within the last 15 years indicates, the high church RBV has been a progressive research program in a number of ways: the understanding of the workings of strategic factors have been much improved; a better understanding of bargaining and value appropriation has been reached; adding transaction costs to the basic model has yielded an increased understanding of value creation and impediments to such value creation, and a deeper understanding of the value of resources has been developed by incorporating demand side factors and transaction costs into the analysis.

Still, the core model has changed rather little as a result of this work, which has tended to refine and elaborate already existing insights rather than yielding fundamentally novel insights. And core RBV theorizing continues to be wedded to a model that originated in mainstream economics in the context of industrial economics. In this sense, a strong intellectual pathdependence has obtained in the history of the RBV.

Although borrowing from the Chicago approach in some ways furthered strategic management, the set of phenomena relevant to strategic management that can be framed by relying on this approach is rather limited. This follows from the basic Chicago research methodology, which casts virtually any social phenomenon in terms of competitive equilibrium—what Chicago School insider Melvin Reder (1982) characterized as the "tight prior equilibrium” assumption. The 
core of this approach is that "in the absence of sufficient evidence to the contrary, one may treat observed prices and quantities as good approximations to their long-run competitive equilibrium values” (Reder, 1982: 12). The resulting notion of competitive equilibrium may not entirely be of the perfect competition (Walrasian) textbook variety, but it is very close. The famous Lippman and Rumelt (1982) paper starts from the standard assumptions of independent profit maximizing decision-makers and competitive markets with free entry. New industry entrants' production processes are assumed to be subject to an ex ante uncertainty (causal ambiguity) in the specific sense that entrants' post-entry cost function is randomly drawn from a known probability distribution after paying a fixed non-retrievable entry investment cost. This produces an equilibrium in which rents persist. Key to generating the desired results is the isolation of new firm production processes - which are assumed to subject ex ante uncertainty-from an otherwise frictionless (competitive) economic environment. Though not cast in formal terms, later key contributions to the RBV adopt essentially this model as the founding model. ${ }^{3}$ The low-church RBV very clearly differs with respect to intellectual pedigree, and its emergence can to a certain be understood in the context of the constraining nature of the equilibrium-based High Church RBV (Foss, 2000; Mathews, 2010).

\section{THE LOW CHURCH RESOURCE-BASED VIEW}

\section{Origins}

Encompassing the "knowledge-based view of the firm” (Kogut \& Zander, 1992;...), the “evolutionary theory of the firm” (Nelson \& Winter, 1982), the “capabilities view of the firm” (..),

\footnotetext{
${ }^{3}$ As Foss and Hallberg (2010) argue the Lippman and Rumelt model and its later verbal RBV counterparts are instances of a specific economic modeling methodology in which imperfections are introduced in a piecemeal manner into a world that is otherwise perfect in order to generate a specific result. As an example, the foundational RBV high church models take factor markets to be imperfects, while product markets are assumed to be perfect (i.e., competitive).
} 
and the "dynamic capabilities view" (Teece, Pisano, and Shuen, 1997), the origins of the low church RBV are more diverse than is the case of the high church RBV, some of its pedigrees lie outside of economics, and many lie within heterodox economics. Thus, the low church RBV draws on the product development and knowledge management literatures in management, evolutionary economics, Schumpeterian thought, the organizational learning literature, work on leadership and alliances, business history, as well as the Penrose's thought. Thus, the low church RBV is the contemporary heir to the Penrose who stressed that "One of the primary assumptions of the theory of the growth of firms is that 'history matters'; growth is essentially an evolutionary process and based on the cumulative growth of collective knowledge, in the context of a purposive firm" (1959[1995]: xiii). What is more, in light of only modest empirical support for the RBV, Newbert (2007) argues that a firm's organizing context and its dynamic capabilities rather than its static resources are essential for understanding competitive positions and superior profitability. Hence, the low church approach to the RBV might not only offer a different theoretical perspective, but may also help to address certain empirical shortcomings of the RBV.

\section{Key Tenets}

Whereas the high church version of the RBV is founded on economic equilibrium and maximizing behaviour, and generates its predictions in the time-honoured manner of selectively introducing imperfections in an otherwise perfect world, the low church RBV is a much more amorphous collection of insights that in some dimensions overlap with the high church RBV. Thus, overall there is the same emphasis on firms as collections of heterogeneous resources.

However, the high church RBV focus on given resources that, moreover, tend to be seen as efficiently organized within a firm. In contrast, the low church RBV focuses on building, accumulating, transforming, managing, learning about, combining and recombining, etc. resources, and, in particular, the services that can be derived from such resources. Dynamics and learning are 
key in the low church RBV. Moreover, whereas the high church RBV is hesitant to privilege any specific resource category, the low church RBV unambiguously concentrates on resources or assets that are knowledge-based, social in the sense that they are somehow linked to a collectivity of interacting agents (Felin \& Foss, 2005), and tend to put much emphasis on the tacit nature of the knowledge that is alleged to reside in such interaction. Notions of "capabilities," "dynamic capabilities," "routines" and the like capture these characteristics.

Though clearly anticipated in Nelson and Winter’s (1982) notion of “dynamic routines” and in the innovation literature (e.g., notions of “dynamic efficiency”, Klein, 1977), research on (dynamic) capabilities was rejuvenated by Teece et al. (1997) who argued that superior performance comes from a firm's capacity to change its resource base in the face of Schumpeterian competition and environmental change. Dynamic capabilities are defined as the firm's ability to integrate, build, and reconfigure internal and external competences to address rapidly changing environments (Teece, Pisano \& Shuen 1997: 516). Importantly, dynamic capabilities reflect past learning processes, as they are a learned pattern of collective activity through which the organization systematically generates and modifies its operational routines in pursuit of improved performance. This basic definition has been subsequently refined and extended (e.g. Winter, 2000, Eisenhardt \& Martin, 2000; Zollo \& Winter, 2002; Teece, 2007; Di Stefano et al., 2010). What unites different approaches and definitions is the insistence on an organizational ability to alter its resource base. Thus, Helfat et al. (2007: 4) synthesize prior conceptual work by defining a dynamic capability as “the capacity of an organization to purposefully create, extend, and modify its resource base”. Accordingly, dynamic capabilities may perform different tasks that alter the resource base, such as new product development, alliance formation, or post-acquisition integration (Eisenhardt \& Martin, 2000). According to the dynamic capability (DC) approach, a firm's capacity to alter its resource base indirectly influences economic profitability (Helfat and Peteraf, 2009). Superior dynamic 
capabilities allow firms enable firms to adapt more quickly and effectively to a changing business environment, creating a stream of temporary competitive advantages over time (Teece et al., 1997; Zott, 2003; Helfat et al., 2007).

Recent work on dynamic capabilities has increasingly stressed the role of organizational processes for understanding how firms alter its resource base. Teece (2007) opens up the black box of dynamic capabilities by relating the concept to organizational processes of sensing and seizing business opportunities and the constant (re)alignment of resources (cf. Helfat and Peteraf, 2009). A firm's sensing ability critically depends on the organizational systems and individual capacities to learn and to identify, filter, evaluate, and shape opportunities. Once a business opportunity is identified, the organizational structure, procedures, and incentives influence whether and how a firm seize the opportunity and creates a new strategic path. What is more, governance and organizational structures shape how firms align their specific resources over time. These “microfoundations” of dynamic capabilities (Teece 2007) link the DC approach to extant research on organizational design and adaptation and on transaction costs and governance structures.

However, despite the popularity of the low-church approach to the RBV in general and dynamic capabilities in particular, many open questions and unresolved issues remain. Williamson (1999) argues that the definition of dynamic capabilities remains overly inclusive and elastic, while Zahra et al. (2006) point to important contradictions in key tenets of the DC approach. For example, while most of the DC literature seems to imply that dynamic capabilities are a fundamental precondition for resource alterations, Helfat and Peteraf (2003) argue that dynamic capabilities are not required for capability building and strategic change. Furthermore, Salvato (2003) and Felin and Foss (2005) point to the lack of proper microfoundations, since extant research fails to demonstrate how individual behaviour (i.e. individual skills) aggregates into collective outcomes (i.e. organizational capability). In a recent critique, Arend and Bromiley (2009) argue that the current 
DC approach offers unclear additional insights relative to existing concepts in the management literature, lacks a coherent theoretical foundation, receives only weak empirical support, and offers diffuse practical implications. Helfat and Peteraf (2009) respond to these criticisms by pointing to the complexity of the research questions which is matched by the complexity of the theoretical underpinnings. What is more, they also claim that the DC approach is still in a state of flux and in its formative stage. According to Helfat and Peteraf (2009: 99), “dynamic capabilities are not yet a theory”.

\section{MOVEMENT TOWARDS THE MIDDLE?}

Changes within the high church as well as the low church RBV have brought them closer to each other. Thus, the low church RBV has become increasingly formal, and although it is does not have a core model in the sense that the high church does, it may be reaching for one. Thus, Gavetti and Levinthal (2004: 1310) explicitly argue that the “... framework of evolutionary economics (Nelson and Winter 1982, 2002) rests on a conceptual apparatus that is quite consistent with the nature of this movement. More specifically, we view it as an emerging archetype, a paradigm, which has the potential to unify this growing middle ground and provide the coherence that is key to the cumulative development of any field of intellectual inquiry.”

In its turn, the high church RBV may have reached the point where further reliance on patched-up competitive equilibrium models does not longer yield progress. In fact, recent advances within this branch of the RBV make use of the language of game theory (Lippman \& Rumelt, 2003; MacDonald \& Ryall, 2004; Adegbesan, 2009) that has supplanted the reliance on competitive equilibrium in economics as the main vehicle of analytical development. ${ }^{4}$ In fact, it is arguable that many RBV contributions have already been pushing the envelope quite significantly. Thus, as Gavetti and Levinthal (2004: 1311) points out, it is arguable that the seminal Dierickx and Cool

\footnotetext{
${ }^{4}$ Although game theoretical work on the RBV tends to be cast in a cooperative mold, rather than the non-cooperative approach that dominates economics.
} 
(1989) paper can be read as a low church contribution: "Within their perspective, actions were not necessarily rational and there was not a presumption of equilibrium ... Although not explicitly linked to the Carnegie School tradition of characterizing organizations as engaged in problemistic search, Dierickx and Cool drew a picture of a firm's capability development that was certainly compatible with such a viewpoint.”

Indeed, the question of how new resources and capabilities are developed is arguably becoming a common theme in both approaches to the RBV. Recent theorizing has stressed that competitive advantage usually does not stem from access to a single, unique resource. Rather, what underpins competitive advantage are complex combinations of co-specialized resources (Peteraf 1993; Levinthal 1997; Knott et al. 2000; Rivkin 2000; Winter 2000; Lippman \& Rumelt 2003; Denrell, Fang \& Winter 2003). The fundamental questions then becomes how firms search for new, valuable resource combinations. The line of inquiry connects RBV thinking to the substantial literature on organizational search and learning. An important theme there is that the search for new resource combinations is not a purely random process, even though luck and serendipity play an essential role in explaining heterogeneous firm performance (Lippman \& Rumelt 1982; Rumelt 1984; Denrell, Fang \& Winter 2003; Denrell 2004). The effectiveness of organizational search is influenced by internal factors such as a firm’s internal structure (Siggelkow \& Levinthal 2003; Rivkin \& Siggelkow 2005; Knudsen \& Levinthal 2007) and external linkages (Rosenkopf \& Nerkar 2001; Holmquist 2004). What is more, goal-setting and performance feedback shape an organization's breadth of search. As many empirical studies have shown, negative performance feedback stimulates explorative search for new resource combinations (Greve 2003 for an overview).

Recent theoretical and empirical research on organizational search similarly suggests that agents use specialized mental models to navigate the vast space of possible resource combinations 
(cf. Nickerson \& Zenger, 2004; Gavetti, 2005; Gavetti \& Rivkin, 2007). In a simulation model, Gavetti and Levinthal (2000) show how the effectiveness of organizational search may be substantially enhanced by cognitive representations of the resource space. A cognitive representation is a simplified picture of the resource space. A well-informed cognitive representation provides guidance in opportunity discovery and allows firms to identify attractive regions in a problem space. Because the cognitive representation is just a coarse-grained depiction of the resource space, an entrepreneur engages in local adaptation to refine the initial business idea. After the discovery of a potentially value-creating resource combination, firms proceed to its refinement and modification (Siggelkow \& Levinthal, 2003; Stieglitz \& Heine 2007; Stiegliz \& Foss, 2009). Hence, what the cognitive representation fundamentally represents is the entrepreneurial expectation and speculation about more attractive regions in the resource space, what Foss, Foss and Klein (2007) call “judgment.”

The key question then is where cognitive representations come from. For technological innovations, an obvious source for a cognitive representation is basic science (Fleming \& Sorensen, 2004). Basic science offers an understanding of causal laws and how certain resources combine and interact in principle. Scientific understanding leads entrepreneurs more directly to useful resource combinations, eliminates fruitless paths of research, and motivates them to press on even in the face of negative feedback (Fleming \& Sorenson, 2004: 911-912). Likewise, a cognitive representation of the resource space may also be informed by analogies (Gavetti, Levinthal \& Rivkin, 2005; Gavetti \& Rivkin, 2007; Gavetti \& Warglien, 2007). Analogies allow human agents to take insights developed in one context and apply it to a new setting. More generally, an important source of competitive advantage is the heterogeneity of expectations and cognitive representations held by human agents in an economy. 
Such a reading is developed by Foss and Foss (2008) who, drawing on the resource-based view, argue that firm-level entrepreneurial opportunities emerge along paths shaped by the firm's experience. However, they also argue out that property rights and transaction cost considerations are important to understanding the discovery and exploitation of opportunities. Two mechanisms link transaction costs and opportunity discovery. First, transaction costs determine how well defined and enforced property rights to resource attributes are; in turn, this influences the value that entrepreneurial resource owners expect to appropriate, and therefore their incentives to engage in opportunity discovery. This is the “appropriability mechanism.” Second, entrepreneurial experience influences opportunity discovery (e.g., Shane, 2000). However, experience (also) emerges from resource learning, that is, entrepreneurs’ learning about the attributes of resources (Mahoney, 1995). Such learning entails transaction costs, for example, the costs of measuring the productivity potential of employees. The transaction costs that entrepreneurs face influence their resource learning, introduce path dependence in such learning, and therefore influence which opportunities will be discovered (the "resource learning mechanism”). In other words, the mental models firms ('managers) adopted from their learning experience of available opportunities are influenced transaction costs and property rights. Although embedded in the resource-based view and property rights economics, the approach of Foss and Foss is thus akin to recent attempts to include learning mechanisms in transaction cost economics (Mayer \& Argyres, 2004; Argyres \& Mayer, 2007).

\section{CONCLUSIONS}

As we have argued the various contributions that make up modern resource-based theory draw from a large and heterogenous set of influences. To be sure, many of the key ideas can be found in the work of the matriarch of the resource-based view, Edith Penrose (1959), but not all of them, and in certain ways her work contains insights that are still to be addressed in modern theory. Thus, the key idea of heterogeneity as key to understanding phenomena of strategic interest is, of course, in 
Penrose's work. However, Penrose stressed the role of heterogeneous services rather than of resources per se, and the role of the administrative framework of the firm as well as management in shaping the kind of services that the resources under the control of the firm can yield. In fact, a key concern in her book is management's actions with respect to resources, that is, processes of acquiring, bundling, leveraging, etc. resources (cf. Kraaijenbrink et al., 2010). This is not a concern in modern theory to the same extent. As Barney and Arikan (2001: 174) admit, the (high-church) RBV has "a very simple view about how resources are connected to the strategies that a firm pursues.” Relatedly, Crook et al. (2008) argued that contingencies related to managerial choice should be a major research area within the RBV. More generally, Felin and Foss (2005) argued that action and interaction in general should be more prominently featured in the RBV in order to understand the emergence, maintenance, change, etc. of firm-level capabilities. A potentially fruitful avenue of research that fulfills some of these more "individual-centric" concerns is represented by a string of recent contributions that link the RBV to research on entrepreneurship (Zahra \& Dess 2001; Alvarez \& Barney, 2005).

In certain key ways, these ideas also hark back to the other important ancestor of the RBV, Harold Demsetz. Demsetz (1973: 3) attributes superior performance to the "combination of great uncertainty plus luck or atypical insight by the management of a firm.” What is more, if information acquisition is costly, managers and their ability to sense and seize business opportunities and effectively recombine resources, becomes more specialized over time (Alchian \& Demsetz 1972; Demsetz, 1988). This line of thinking places more emphasis on decision-making and the individual ability to search and evaluate resource combinations. A number of contributions highlight individual cognition in structuring the search for new resource combinations (e.g. Amit \& Schoemaker, 1993; Foss, 1993; Gavetti \& Levinthal, 2000, Gavetti, Levinthal \& Rivkin, 2005; Knudsen \& Levinthal, 2007), but these ideas do not seem to be well integrated into the core of the 
RBV. In addition, the decision-making process about resource allocation and capability development is structured by the organization design (Adner \& Levinthal, 2004; Gavetti, 2005; Foss, Foss \& Klein, 2007; Christensen \& Knudsen, 2010). Lastly, the incentive system of a firm influences where and how a firm searches for new resource combinations (Manso, 2008). In a nutshell, it appears that the RBV stands to gain from a more careful consideration of individual and organizational factors that influence how a firm searches and evaluates resource combinations and allocates resources. In terms of drawing on neighboring fields, the operational implications seem to be that the RBV may stand to gain from linking up more explicitly with research on strategic human resource management and top management teams.

Finally, another area for further research is the development of (formal) models that would facilitate the cumulative buildup of theoretical knowledge and careful development of empirical hypotheses. While the RBV has a long tradition of formal models (e.g. Lippman \& Rumelt, 1982; Makadok, 2001; Lippman \& Rumelt, 2003; Denrell, 2004; MacDonald \& Ryall, 2004), these contributions appear to represent a fringe rather than a widely accepted theoretical core of RBV thinking. For example, it is unclear how a standard model in the RBV looks like that connects differential resource advantage to product market competition (e.g., Klepper \& Simmons 2000), although this issue is beginning to be explored (Asmussen, 2010; Makadok, 2010). Does the NK model — widely applied to problems of organizational search and adaptation-represent an adequate model platform to study how firms engage in resource learning, recombine resources, and protect them from competition? To what extent can RBV theory draw on formal theories of the firm that link resource investments to the bargaining positions of resource owners and other factors (Gibbons, 2005)? It is noteworthy that formal arguments have been brought to bear on issues both within the high- and the low church RBV. Perhaps the movement towards the middle that we have diagnosed 
will be prompted by formal developments, and the long-standing schism within the RBV will finally be overcome.

\section{REFERENCES}

Acedo, F. J., Barroso, C., and Galan J. L. 2006. "The resource-based theory: Dissemination and main trends,” Strategic Management Journal, 27: 621-636.

Adegbesan, A. J. 2009. "On the origins of competitive advantage: Strategic factor markets and heterogeneous resource complementarity,” Academy of Management Review, 34: 463-475.

Adner, R., D.A. Levinthal. 2004. "What is not a real option: Considering boundaries for the application of real options to business strategy". Academy of Management Review 29: 7485.

Arend, R. J. \& Bromiley, P. (2009) “Assessing the dynamic capabilities view: spare change, everyone?”. Strategic Organization, 7: 75-90.

Agarwal, R. and G. Hoetker. 2007. A Faustian bargain? The growth of management and its relationship with related disciplines. Academy of Management Journal, 50: 1304-1322.

Alchain, A.A. and Demsetz, H. 1972. "Production, Information Costs and Economic Organization”. American Economic Review, 62:777-795.

Alvarez, S. and J.B. Barney. 2005. "How Do Entrepreneurs Organize Firms Under Conditions of Uncertainty?,” Journal of Management, 31: 776-793.

Amit, R. and Schoemaker, P. 1993. "Strategic assets and organizational rent." Strategic Management Journal, 14: 33-46.

Arend, R.J. 2006. “Tests of the resource-based view: do the empirics have any clothes?,” Strategic Organization, 4: 409-421.

Argyres, N.S. amd K. J. Mayer 2007. "Contract Design As a Firm Capability: An Integration of Learning and Transaction Cost Perspectives.” Academy of Management Review 32: 1060 1077.

Armstrong, C.E. and Shimizu, K. 2007. "A Review of Approaches to Empirical Research on the Resource-Based View of the Firm”. Journal of Management, 33 (6): 959-986.

Asmussen, C.G. 2010. “Chicken, Stag, or Rabbit? Strategic Factor Markets and the Moderating Role of Downstream Competition,” Working Paper, Center for Strategic Management and Globalization, Copenhagen Business School.

Bain, J.S. 1956. Barriers to New Competition. Cambridge: Harvard University Press.

Barney, J. B. 1986. "Strategic factor markets: Expectations, luck, and business strategy." Management Science, 32: 1231-1241.

Barney, J. B. 1991. "Firm resources and sustained competitive advantage." Journal of Management, 17: 99-120. 
Barney, J. B. 1995. “Looking inside for competitive advantage.”Academy of Management Executive, 9: 49-61.

Barney, J. B. 2001. "Is the resource-based "view" a useful perspective for strategic management research? Yes" The Academy of Management Review, 26: 41-56.

Barney, J.B. and A.M. Arikan. 2001. “The resource-based view: Origins and implications,” in M.A. Hitt, R.E. Freeman, and J.S. Harrison, eds. 2001. Handbook of Strategic Management. Oxford: Basil Blackwell.

Baumol, W. J., Panzar, J. C. and Willig, R. D. 1982. "Contestable Markets: An Uprising in the Theory of Industry Structure: Reply.” The American Economic Review 73 (3).

Blyler, M. and Coff, R.W. 2003. "Dynamic Capabilities, Social Capital, and Rent Appropriation: Ties that Split Pies ”. Strategic Management Journal, 24: 677-686.

Brandenburger, A., and Stuart, H. 2007. “Biform games.” Management Science, 53: 537-550.

Brozen, Y. 1971 "The Persistence of 'High Rates of Return' in High-Stable Concentration Industries,” Journal of Law and Economics 14: 501-512.

Camerer, C. 1994. Does strategy research need game theory? In R. P. Rumelt, D. Schendel and D. J. Teece, eds. 1994. Fundamental issues in strategy. Boston: Harvard Business School Press.

Capron, L. and Pistre, N., 2002. “When do acquirers earn abnormal returns?” Strategic Management Journal 23: 781-794.

Capron, L. and Shen, J.C. 2007. "Acquisitions of private vs. public firms: Private information, target selection, and acquirer returns”. Strategic Management Journal, 28 (9): 891-911.

Chi, T., 1994. Trading in Strategic Resources: Necessary Conditions, Transaction Cost Problems, and Choice of Exchange Structure. Strategic Management Journal 15: 271-290.

Christensen, M., \& Knudsen, T. 2010. "Design of Decision-Making Organizations”. Management Science, 56(1): 71-89.

Coase, R.H.1937 “The Nature of the Firm”. Economica, New Series, 4 (16): 386-405.

Coase, R.H. 1960. “The problem of Social Cost”. Journal of Law and Economics, 3:1-44.

Coff, R. 1997. "Human assets and management dilemmas: Coping with hazards on the road to resource-based theory”. Acad. Management Rev. , 22(2): 374-402.

Coff, R. W. 1999. When competitive advantage doesn’t lead to performance: The resource-based view and stakeholder bargaining power. Organization Science, 10: 119-133.

Cohen, W.M and Levinthal, D.A. 1990. “Absorptive Capacity: A New Perspective on Learning and Innovation “.Administrative Science Quarterly, 35 (1):128-152.

Conner, K. 1991. "A Historical Comparison of Resource-based Theory and Five Schools of Thought within Industrial Organization Economics: Do We Have a New Theory of the Firm?”.Journal of Management, 17:121-154.

Conner, K.R. and Prahalad, C.K. 1996. "A Resource-Based Theory of the Firm: Knowledge versus Opportunism”. Organization Science, 7 (5): 477-501.

Crook, T. R., Ketchen, D. J., Combs, J. G., \& Todd, S. Y. 2008. "Strategic resources and performance: a meta-analysis". Strategic Management Journal, 29(11): 1141-1154. 
David G. Hoopes, D.G. and Madsen T. L. 2008. “A capability-based view of competitive Heterogeneity”. Industrial and Corporate Change, April: 1-34.

Debreu, G. 1959. Theory of value. New York: Wiley.

Demsetz, H.. 1973. "Industrial Structure, Market Rivalry, and Public Policy”, Journal of Law and Economics 16: 1-10.

Demsetz, H.. 1974. "Two Systems of Belief About Monopoly”, in idem. 1989. Efficiency, Competition, and Policy. Oxford: Basil Blackwell.

Demsetz, H.. 1982. "Barriers to Entry”, in idem. 1989. Efficiency, Competition, and Policy. Oxford: Basil Blackwell.

Demsetz, H. 1988. “The Theory of the Firm Revisited”. Journal of Law, Economics, \& Organization, 4 (1):141-161

Demsetz, H. 1989. “The Indivisibility Rent Theory of Measured Oligopoly Profit”, in idem. 1989. Efficiency, Competition, and Policy. Oxford: Basil Blackwell.

Denrell, J., Fang, C. and Winter, S. G.. 2003. “The Economic of Strategic Opportunity.” Strategic Management Journal, 24: 977-990.

Denrell, J. 2004."Random Walks and Sustained Competitive Advantage”. Management Science, 50 (7): 922-934.

Dierickx, I. and Cool, K. 1989. “Asset Stock Accumulation and the Sustainability of Competitive Advantage”. Management Science 35: 1504-11.

Di Stefano, G., Peteraf, M., \& Verona, G. 2010. "Dynamic capabilities deconstructed: a bibliographic investigation into the origins, development, and future directions of the research domain”. Industrial and Corporate Change, 19(4): 1187 -1204.

Eisenhardt, K.M, and Martin, J.A. 2000. “Dynamic Capabilities: What Are They? “. Strategic Management Journal, 21 (10/11): 1105- 1121 Special Issue: The Evolution of Firm Capabilities.

Fama, E. F. 1970. Efficient capital markets: A review of theory and empirical work. Journal of Finance, 25: 383-417.

Felin, T. and N.J. Foss. 2005. "Strategic Organization: a Field in Search of Microfoundations.” Strategic Organization 3: 441-455.

Fleming, L. 2001. "Recombinant Uncertainty in Technological Search”. Management Science 47: 117-132.

Fleming, L. and O. Sorenson. 2004. "Science as a map in technological search.” Strategic Management Journal 25: 909-928.

Foss, N.J. 1993. "The theory of the firm: Contractual and competence perspectives.” Journal of Evolutionary Economics, 3:127-144.

Foss, N. J. 1996. "Knowledge-based approaches to the theory of the firm: Some critical comments". Organization Science, 7: 470-476.

Foss, N.J. 1998. Thorstein B. Veblen: Precursor of the Competence-Based Approach to the Firm,” Cambridge Journal of Economics, 22: 479-495.

Foss, Nicolai J. 2000. "Equilibrium vs Evolution in the Resource-based Perspective,” in Nicolai J. 
Foss and Paul L. Robertson, eds. 2000. Resources, Technology, and Strategy. London: Routledge.

Foss, N.J. 2003. The Strategic Management and Transaction Cost Nexus: Past Debates, Central Questions, and Future Research Possibilities,” Strategic Organization, 1: 139-169.

Foss, K., and Foss, N. J. 2005. "Resources and transaction costs: How property rights economics furthers the resource-based view.” Strategic Management Journal, 26: 541-553.

Foss, K., and Foss, N. J. 2008. "Understanding Opportunity Discovery and Sustainable Advantage: the Role of Transaction Costs and Property Rights.” Strategic Entrepreneurship Journal, 2: 191-207.

Foss, K., N.J. Foss and P.G. Klein. 2007. "Original and Derived Judgment: an Entrepreneurial Theory of Economic Organization,” Organization Studies, 28: 1893-1912.

Foss, N.J. and N. Hallberg. 2010. "Symmetry and Theoretical Isolation in the Resource-based View,” Working Paper.

Foss, N. J., \& Knudsen, T. 2003. "The resource-based tangle: Towards a sustainable explanation of competitive advantage. Managerial and Decision Economics, 24: 291-307.

Furubotn, E., and Richter, R. 1997. Institutions and economic theory. Ann Arbor: Michigan University Press.

Gavetti, G. and Levinthal, D.A. 2000. "Looking forward and looking backward: Cognitive and experiential search.” Administrative Science Quarterly 45: 113-137.

Gavetti, G. and Levinthal, D.A. 2004. "The strategy field from the perspective of management science: Divergent strands and possible integration.” Management Science, 50: 1309-1318.

Gavetti, G. 2005. "Cognition and Hierarchy: Rethinking the Microfoundations of Capabilities' Development.” Organization Science 16: 599-617.

Gavetti, G., D. A. Levinthal, J.W. Rivkin. 2005. "Strategy making in novel and complex worlds: the power of analogy.” Strategic Management Journal 26: 691-712.

Gavetti, G. and M. Warglien 2007. "Recognizing the New: A Multi-Agent Model of Analogy in Strategic Decision-Making." Harvard Business School Working Paper, No. 08-028, October 2007.

Gavetti, G., \& Rivkin, J. W. 2007. “On the Origin of Strategy: Action and Cognition over Time”. Organization Science, 18(3): 420-439.

Ghemawat, P. 1991. Commitment: The Dynamic of Strategy. New York: The Free Press.

Gibbons, R. 2005. “Four Formal(izable) Theories of the Firm?” Journal of Economic Behavior and Organization 58: 202-47.

Greve, H.R. 2003. Organizational Learning from Performance Feedback. Cambridge: Cambridge University Press

Hamel, G.. and Prahalad, C.K. 1994. Competing for the Future. Boston: Harvard Business School Press.

Heimriks, K. H., Fellin, T., Foss, N. J., and Zollo, M. 2010. "A Comparative Review of the Resource, Routines, and Capabilities Literatures: Similarities, Differences and a Proposed Agenda, Working Paper. 
Helfat, C. E. and Peteraf, M. A. 2003. "The Dynamic Resource-based View: Capability Life Cycles”. Strategic Management Journal, 24: 997-1010.

Helfat, C.E. et al., 2007. Dynamic Capabilities: Understanding Strategic Change in Organizations. Oxford: Blackwell.

Helfat, C. E. and Peteraf, M. A. 2009. "Understanding dynamic capabilities: progress along a developmental path”. Strategic Organization, 7: 91-102

Holmqvist, M. 2004. "Experiential Learning Processes of Exploitation and Exploration within and between Organizations: An Empirical Study of Product Development.” Organization Science 15: 70-81.

Hoskisson, R. E., Hitt, M. A., Wan, W. and Yiu, D. 1999. "Theory and research in strategic management: Swings of a pendulum”. Journal of Management vol. 25 no. 3 :417-456.

Jacobson, R. 1992. "The Austrian School of Strategy. ” Academy of Management Review 17: 782807.

Jacobides, M.G., Knudsen, T. and Augier, M., 2006. "Benefiting from innovation: Value creation, value appropriation and the role of industry architectures.” Research Policy 35: 1200-1221.

Kauffman, S.A. 1993. Origins of Order: Self-Organization and Selection in Evolution. Oxford: Oxford University Press.

Kim, J. and Mahoney, J.T. 2002. "Resource-Based and Property Rights Perspectives on Value Creation: The Case of Oil Field Unitization”. Managerial and Decision Economics, 23 (4/5): 225-245 Conversations on the Dynamics, Context, and Consequences of Strategy.

Kim, J., and Mahoney, J. T. 2005. "Property rights theory, transaction costs theory, and agency theory: An organizational economics approach to strategic management." Managerial and Decision Economics, 26: 223-242.

King, A.W. and Zeithaml, C.P. 2001."Competencies and Firm Performance: Examining the Causal Ambiguity Paradox”. Strategic Management Journal, 22 (1): 75-99.

Klein, B., Crawford, R.G. and Alchian, A.A. 1978 "Vertical Integration, Appropriable Rents, and the Competitive Contracting Process”. Journal of Law and Economics, 21(2): 297-326.

Klein, K. J., Tosi, H., and Cannella, A. A Jr. 1999. Multilevel theory building: Benefits, barriers, and new developments. The Academy of Management Review, 24: 243-248.

Klepper, S. and Simons, K.L. 2000. “ The making of an oligopoly: firm survival and technological change in the evolution of the US tire industry”. Journal of Political Economy,108:728-760.

Knight, F. H. 1921. Risk, Uncertainty, and Profit. New York: August M. Kelley.

Knott, A.M. 2003. “The Organizational Routines Factor Market Paradox,” Strategic Management Journal, 24: 929-943.

Knott, A. M., Bryce, D. J., \& Posen, H. E. 2003. “On the Strategic Accumulation of Intangible Assets”. Organization Science, 14(2): 192-207.

Knudsen, T. amd D.A. Levinthal. 2007. "Two faces of search: Alternative generation and alternative evaluation.” Organization Science 18 39-54.

Kogut, B. and Zander, U. 1992. Knowledge of the firm, combinative capabilities, and the replication of technology. Organization Science, 3: 383-397. 
Kor, Y. Y. and Mahoney, J. T. 2000. "Penrose’s Resource-Based Approach: The Process and Product of Research Creativity.” Journal of Management Studies 37(1): 109-39.

Kraaijenbrink, J. J.-C. Spender and A. J. Groen. 2010. “The Resource-Based View: A Review and Assessment of Its Critiques,” Journal of Management, 36: 349-372.

Levinthal, D. 1997. “Adaptation on Rugged Landscapes,” Management Science 43: 934-950.

Lippman, S. A., and Rumelt, R. P. 1982. Uncertain imitability: An analysis of interfirm differences in efficiency under competition. The Bell Journal of Economics, 13: 418-438.

Lippman, S. A., and Rumelt, R. P. 2003a. A bargaining perspective on resource advantage. Strategic Management Journal, 24: 1069-1086.

Lippman, S. A., and Rumelt, R. P. 2003b. The payments perspective: Micro-foundations of resource analysis. Strategic Management Journal, 24: 903-927.

Lockett, A. and S. Thompson. 2001. “The Resource-based View and Economics,” Journal of Management, 27: 723-724.

MacDonald, G., and Ryall, M. D. 2004. How do value creation and competition determine whether a firm appropriates value? Management Science, 50: 1319-1334.

Machovec, F, M. 1995. Perfect Competition and the Transformation of Economics. London: Routledge.

Mahoney, J. T. 1995.” The management of resources and the resource of management.” Journal of Business Research, 33: 91-101.

Mahoney, J. T., and Pandian J. R. 1992. "The resource-based view within the conversation of strategic management.” Strategic Management Journal, 13: 363-380.

Mahoney, P.G. 2001.“The Common Law and Economic Growth: Hayek Might Be Right”. The Journal of Legal Studies, 30 (2): 503-525.

Makadok, R, and Coff, R. 2002. "The theory of value and the value of theory: Breaking new ground versus reinventing the wheel.” The Academy of Management Review, 27: 10-13.

Makadok, R. 2001a.”A pointed commentary on Priem and Butler.” Academy of Management Review, 26: 498-499.

Makadok, R. 2001b. “Toward a Synthesis of the Resource-Based and Dynamic-Capability Views of Rent Creation.” Strategic Management Journal 22: 387-401.

Makadok, R. and Barney, J.B. 2001. “Strategic Factor Market Intelligence: An Application of Information Economics to Strategy Formulation and Competitor Intelligence.” Management Science 47: 1621-1638.

Makadok, R. 2010. "The Interaction Effect of Rivalry Restraint and Competitive Advantage on Profit: Why the Whole Is Less Than the Sum of the Parts," forthcoming in Management Science.

Makowski, L. and Ostroy, J. M.. 2001. "Perfect Competition and the Creativity of Markets," Journal of Economic Literature 39: 479-435.

Manso, G. 2008. “Motivating Innovation.” MIT Working Paper 2008.

Mathews, J. A. 2006. Strategizing, disequilibrium and profits. Stanford, CA: Stanford University Press. 
Mathews, J. A. 2010. Lachmannian Insights into Strategic Entrepreneurship: Resources, Activities and Routines in a Disequilibrium World. Organization Studies, 31: 219-244.

Mayer, K.J. and Argyres, N.S. 2004. "Learning to Contract: Evidence from the Personal Computer Industry”. Organization Science, 15 (4): 394-410.

Montgomery, C.A.. and Wernerfelt, B. 1988. "Diversification, Ricardian Rents, and Tobin’s Q,”. Rand Journal of Economics 19(4): 623-632.

Mosakowski, E. 1997. “Strategy Making under Causal Ambiguity: Conceptual Issues and Empirical Evidence.” Organization Science, 8(4), 414-442.

Nelson, R. R., and Winter S. G. 1982. An evolutionary theory of economic change. Cambridge, MA: Belknap Press.

Nelson, R. R., \& Winter, S. G. 2002. "Evolutionary Theorizing in Economics”. The Journal of Economic Perspectives, 16(2): 23-46.

Newbert, S. L. 2007. Empirical research on the resource-based view of the firm: An assessment and suggestions for future research. Strategic Management Journal, 28: 121-147.

Nickerson, Jackson and Zenger, Todd. 2004. “A Knowledge-based Theory of the Firm: The Problem-Solving Perspective”. Organization Science 15(6): 617-632

Peltzman, S. 1977. "The Gains and Losses from Industrial Concentration”. Journal of Law and Economics 20: 229-263.

Penrose, Edith T. 1959. The Theory of the Growth of the Firm. Oxford: Oxford University Press.

Peteraf, M. A. 1993. The cornerstones of competitive advantage: A resource-based view. Strategic Management Journal, 14: 179-191.

Peteraf, M. A., and Barney, J. B. 2003. Unraveling the resource-based tangle. Managerial and Decision Economics, 24: 309-323.

Prahalad, C.K. and Hamel, G. 1990. “The core competence and the corporation”. Harvard Business Review, 71-91.

Porter, M. 1980. Competitive strategy. New York: The Free Press.

Porter, Michael E .1981. “The Contribution of Industrial Organization to Strategic Management”. Academy of Management Review 6(4).

Powell, T. C. 2001. Competitive advantage: Logical and philosophical considerations. Strategic Management Journal, 22: 875-888.

Priem, R. L. 2007. A consumer perspective on value creation. The Academy of Management Review, 32: 219-235.

Priem, R. L., and Butler, J. E. 2001. Is the resource-based "view" a useful perspective for strategic management research? The Academy of Management Review, 26: 22-40.

Priem, R. L., and Butler, J. E. 2001. Tautology in the resource-based view and the implications of externally determined resource value: Further comments. The Academy of Management Review, 26: 57-66.

Priem, R.L.. and Butler, J. E. 2001a. "Is the Resource Based "View" a Useful Perspective for Strategic Management Research?” Academy of Management Review 26 (1): 22-40. 
Rasmusen, E. 1989. Games and information. Oxford: Blackwell Publishers.

Reder, M W. 1982. “Chicago Economics: Permanence and change”. Journal of Economic Literature. Vol. XX.

Reed, R. and Defillippi, R.J. 1990. "Causal Ambiguity, Barriers to Imitation, and Sustainable Competitive Advantage “.The Academy of Management Review, 15 (1): 88-102.

Richardson, G.B. 1972. “The Organisation of Industry”. The Economic Journal, Vol. 82, No. 327: 883-896.

Rivkin, Jan. 2000. “Imitation of Complex Strategies”. Management Science 46: 824-844.

Roberts, Peter W. and Eisenhardt, K.M. 2003. “Austrian Insights on Strategic Organization: From Market Insights to Implications for Firms”. Strategic Organization 1: 345-52.

Robinson, J. 1934. What is perfect competition?. Quarterly Journal of Economics, 49: 104-121.

Porter, M.E. 1985. “Competitive Advantage: Creating and Sustaining Superior Performance”. Free Press, New York.

Rivkin, J. W. 2001. "Reproducing Knowledge: Replication without Imitation at Moderate Complexity”. Organization Science, 12(3): 274-293.

Rosenkopf, L. and Nerkar, A. 2001. "Beyond Local Search: Boundary-Spanning, Exploration, and Impact in the Optical Disk Industry”. Strategic Management Journal, 22 (4): 287-306.

Rumelt, R. P. 1984. “Towards a Strategic Theory of the Firm,” in Richard B. Lamb, ed. Competitive Strategic Management. New Jersey: Englewood Cliffs.

Rumelt, R. P. 1987. “Theory, Strategy, and Entrepreneurship,” in D. J. Teece (ed.). The Competitive challenge: Strategies for industrial innovation and renewal. 137-158. Cambridge, MA: Ballinger.

Rumelt, R.P., Schendel, D. and Teece, D.J. 1991. "Strategic Management and Economics". Strategic Management Journal, 12: 5-29.

Ryall, M.D., J. S. Gans and G. MacDonald. 2008. The two sides of competition and their implications for strategy. Unpublished manuscript, available at: http://works.bepress.com/michael_ryall/15

Salvato, C. 2003. “The Role of Micro-Strategies in the Engineering of Firm Evolution”. Journal of Management Studies, 40(1): 83-108.

Scherer, F.M. 1980. Industrial Market Structure and Economic Performance. Boston: Houghton Mifflin.

Schumpeter, Joseph A. 1911. The Theory of Economic Development: An Inquiry into Profits, Capital, Credit, Interest, and the Business Cycle. Translated by Redvers Opie. Cambridge, Mass.:Harvard University Press, 1934.

Shane, Scott 2003. A General Theory of Entrepreneurship: The Individual-Opportunity Nexus. Aldershot, UK: Edward Elgar.

Shane, Scott. 2000. "Prior Knowledge and the Discovery of Entrepreneurial Opportunities". Organization Science 11 (4): 448-469.

Siggelkow, N. and D.A. Levinthal. 2003. Temporarily Divide to Conquer: Centralized, Decentralized, and Reintegrated Organizational Approaches to Exploration and Adaption. 
Organization Science 14: 650-669.

Siggelkow, N. and J.W. Rivkin. 2005. Speed and Search: Designing Organizations for Turbulence and Complexity. Organization Science 16: 101-122.

Silverman, B.S. 1999. "Technological Resources and the Direction of Corporate Diversification: Toward an Integration of the Resource-Based View and Transaction Cost Economics". Management Science, 45 (8): 1109-1124.

Simon, Herbert A. 1955. “A Behavioral Model of Rational Choice”. Quarterly Jounal of Economics 69: 99-118.

Stieglitz, N. and Heine, K. 2007. "Innovations and the role of complementarities in a strategic theory of the firm.” Strategic Management Journal 28: 1-15.

Stieglitz, N. and Foss, N.J. 2009. “Opportunities and New Business Models: Transaction Cost and Property Rights Perspectives on Entrepreneurship”. Working Paper.

Teece, D.J. 1986. “Profiting from technological innovation”. Research Policy, 15: 286-305.

Teece, D. J., Pisano, G. and Shuen, A. 1997. “Dynamic Capabilities and Strategic Management”. Strategic Management Journal 18(7): 509-533.

Teece, D.J. 2007. "Explicating dynamic capabilities: The nature and microfoundations of (sustainable) enterprise performance.” Strategic Management Journal 28: 1319-1350.

Tirole, Jean. 1988. The Theory of Industrial Organization. Cambridge, MA: MIT Press.

Wernerfelt, Birger. 1984. “A Resource-based View of the Firm”. Strategic Management Journal 5: 171-180.

Williamson, O. E. 1985. The economic institutions of capitalism. New York: Free Press.

Williamson, O.E. 1996. “The Mechanisms of Governance”.NY: Oxford U. Press.

Williamson, O.E. 1999. "Strategy research: Governance and competence perspectives". Strategic Management Journal, 20:1087-1108.

Winter, S. G. 2000. “The Satisficing Principle in Capability Learning”. Strategic Management Journal, 21(10/11): 981-996.

Winter, S.G. and Szulanski, G. 2001: “Replication as Strategy”. Organization Science, 12 (6): 730743.

Zahra, S. and Dess, G.G. 2001. "Entrepreneurship as a Field of Research: Encouraging Dialogue and Debate". The Academy of Management Review, 26 (1): 8-10.

Zahra, S.A., Sapienza, H.J. and Davidsson, P. 2006. “Entrepreneurship and Dynamic Capabilities: A Review, Model and Research Agenda*”. Journal of Management Studies 43 (4): 917-955.

Zollo, M. and Winter, S.G. 2002. "Deliberate Learning and the Evolution of Dynamic Capabilities“. Organization Science, 13 (3): 339-351, Knowledge, Knowing, and Organizations.

Zott, C. 2002. "Dynamic capabilities and the emergence of intraindustry differential firm performance: insights from a simulation study". Strategic Management Journal, 24 (2): 97125. 


\section{SMG - Working Papers \\ www.cbs.dk/smg \\ 2003}

2003-1: Nicolai J. Foss, Kenneth Husted, Snejina Michailova, and Torben Pedersen: Governing Knowledge Processes: Theoretical Foundations and Research Opportunities.

2003-2: Yves Doz, Nicolai J. Foss, Stefanie Lenway, Marjorie Lyles, Silvia Massini, Thomas P. Murtha and Torben Pedersen: Future Frontiers in International Management Research: Innovation, Knowledge Creation, and Change in Multinational Companies.

2003-3: Snejina Michailova and Kate Hutchings: The Impact of In-Groups and OutGroups on Knowledge Sharing in Russia and China CKG Working Paper.

2003-4: Nicolai J. Foss and Torben Pedersen: The MNC as a Knowledge Structure: The Roles of Knowledge Sources and Organizational Instruments in MNC Knowledge Management CKG Working Paper.

2003-5: Kirsten Foss, Nicolai J. Foss and Xosé H. Vázquez-Vicente: “Tying the Manager's Hands": How Firms Can Make Credible Commitments That Make Opportunistic Managerial Intervention Less Likely CKG Working Paper.

2003-6: Marjorie Lyles, Torben Pedersen and Bent Petersen: Knowledge Gaps: The Case of Knowledge about Foreign Entry.

2003-7: Kirsten Foss and Nicolai J. Foss: The Limits to Designed Orders: Authority under "Distributed Knowledge" CKG Working Paper.

2003-8: Jens Gammelgaard and Torben Pedersen: Internal versus External Knowledge Sourcing of Subsidiaries - An Organizational Trade-Off.

2003-9: Kate Hutchings and Snejina Michailova: Facilitating Knowledge Sharing in Russian and Chinese Subsidiaries: The Importance of Groups and Personal Networks Accepted for publication in Journal of Knowledge Management.

2003-10: Volker Mahnke, Torben Pedersen and Markus Verzin: The Impact of Knowledge Management on MNC Subsidiary Performance: the Role of Absorptive Capacity CKG Working Paper.

2003-11: Tomas Hellström and Kenneth Husted: Mapping Knowledge and Intellectual Capital in Academic Environments: A Focus Group Study Accepted for publication in Journal of Intellectual Capital CKG Working Paper.

2003-12: Nicolai J Foss: Cognition and Motivation in the Theory of the Firm: Interaction or "Never the Twain Shall Meet"? Accepted for publication in Journal des Economistes et des Etudes Humaines CKG Working Paper.

2003-13: Dana Minbaeva and Snejina Michailova: Knowledge Transfer and Expatriation Practices in MNCs: The Role of Disseminative Capacity.

2003-14: Christian Vintergaard and Kenneth Husted: Enhancing Selective Capacity Through Venture Bases. 


\section{4}

2004-1: Nicolai J. Foss: Knowledge and Organization in the Theory of the Multinational Corporation: Some Foundational Issues

2004-2: Dana B. Minbaeva: HRM Practices and MNC Knowledge Transfer

2004-3: Bo Bernhard Nielsen and Snejina Michailova: Toward a Phase-Model of Global Knowledge Management Systems in Multinational Corporations

2004-4: Kirsten Foss \& Nicolai J Foss: The Next Step in the Evolution of the RBV: Integration with Transaction Cost Economics

2004-5: Teppo Felin \& Nicolai J. Foss: Methodological Individualism and the Organizational Capabilities Approach

2004-6: Jens Gammelgaard, Kenneth Husted, Snejina Michailova: Knowledge-sharing Behavior and Post-acquisition Integration Failure

2004-7: Jens Gammelgaard: Multinational Exploration of Acquired R\&D Activities

2004-8: Christoph Dörrenbächer \& Jens Gammelgaard: Subsidiary Upgrading? Strategic Inertia in the Development of German-owned Subsidiaries in Hungary

2004-9: Kirsten Foss \& Nicolai J. Foss: Resources and Transaction Costs: How the Economics of Property Rights Furthers the Resource-based View

2004-10: Jens Gammelgaard \& Thomas Ritter: The Knowledge Retrieval Matrix: Codification and Personification as Separate Strategies

2004-11: Nicolai J. Foss \& Peter G. Klein: Entrepreneurship and the Economic Theory of the Firm: Any Gains from Trade?

2004-12: Akshey Gupta \& Snejina Michailova: Knowledge Sharing in Knowledge-Intensive Firms: Opportunities and Limitations of Knowledge Codification

2004-13: Snejina Michailova \& Kate Hutchings: Knowledge Sharing and National Culture: A Comparison Between China and Russia

\section{5}

2005-1: Keld Laursen \& Ammon Salter: My Precious - The Role of Appropriability Strategies in Shaping Innovative Performance

2005-2: Nicolai J. Foss \& Peter G. Klein: The Theory of the Firm and Its Critics: A Stocktaking and Assessment

2005-3: Lars Bo Jeppesen \& Lars Frederiksen: Why Firm-Established User Communities Work for Innovation: The Personal Attributes of Innovative Users in the Case of Computer-Controlled Music

2005-4: Dana B. Minbaeva: Negative Impact of HRM Complementarity on Knowledge Transfer in MNCs

2005-5: Kirsten Foss, Nicolai J. Foss, Peter G. Klein \& Sandra K. Klein: Austrian Capital 
Theory and the Link Between Entrepreneurship and the Theory of the Firm

2005-1: Nicolai J. Foss: The Knowledge Governance Approach

2005-2: Torben J. Andersen: Capital Structure, Environmental Dynamism, Innovation Strategy, and Strategic Risk Management

2005-3: Torben J. Andersen: A Strategic Risk Management Framework for Multinational Enterprise

2005-4: Peter Holdt Christensen: Facilitating Knowledge Sharing: A Conceptual Framework

2005-5 Kirsten Foss \& Nicolai J. Foss: Hands Off! How Organizational Design Can Make Delegation Credible

2005-6 Marjorie A. Lyles, Torben Pedersen \& Bent Petersen: Closing the Knowledge Gap in Foreign Markets - A Learning Perspective

2005-7 Christian Geisler Asmussen, Torben Pedersen \& Bent Petersen: How do we Capture "Global Specialization" when Measuring Firms' Degree of internationalization?

2005-8 Kirsten Foss \& Nicolai J. Foss: Simon on Problem-Solving: Implications for New Organizational Forms

2005-9 Birgitte Grøgaard, Carmine Gioia \& Gabriel R.G. Benito: An Empirical Investigation of the Role of Industry Factors in the Internationalization Patterns of Firms

2005-10 Torben J. Andersen: The Performance and Risk Management Implications of Multinationality: An Industry Perspective

2005-11 Nicolai J. Foss: The Scientific Progress in Strategic Management: The case of the Resource-based view

2005-12 Koen H. Heimeriks: Alliance Capability as a Mediator Between Experience and Alliance Performance: An Empirical Investigation Into the Alliance Capability Development Process

2005-13 Koen H. Heimeriks, Geert Duysters \& Wim Vanhaverbeke: Developing Alliance Capabilities: An Empirical Study

2005-14 JC Spender: Management, Rational or Creative? A Knowledge-Based Discussion

\section{6}

2006-1: Nicolai J. Foss \& Peter G. Klein: The Emergence of the Modern Theory of the Firm

2006-2: Teppo Felin \& Nicolai J. Foss: Individuals and Organizations: Thoughts on a Micro-Foundations Project for Strategic Management and Organizational Analysis

2006-3: Volker Mahnke, Torben Pedersen \& Markus Venzin: Does Knowledge Sharing 
Pay? An MNC Subsidiary Perspective on Knowledge Outflows

2006-4: Torben Pedersen: Determining Factors of Subsidiary Development

2006-5 Ibuki Ishikawa: The Source of Competitive Advantage and Entrepreneurial Judgment in the RBV: Insights from the Austrian School Perspective

2006-6 Nicolai J. Foss \& Ibuki Ishikawa: Towards a Dynamic Resource-Based View: Insights from Austrian Capital and Entrepreneurship Theory

2006-7 Kirsten Foss \& Nicolai J. Foss: Entrepreneurship, Transaction Costs, and Resource Attributes

2006-8 Kirsten Foss, Nicolai J. Foss \& Peter G. Klein: Original and Derived Judgement: An Entrepreneurial Theory of Economic Organization

2006-9 Mia Reinholt: No More Polarization, Please! Towards a More Nuanced Perspective on Motivation in Organizations

2006-10 Angelika Lindstrand, Sara Melen \& Emilia Rovira: Turning social capital into business? A study of Swedish biotech firms' international expansion

2006-11 Christian Geisler Asmussen, Torben Pedersen \& Charles Dhanaraj: Evolution of Subsidiary Competences: Extending the Diamond Network Model

2006-12 John Holt, William R. Purcell, Sidney J. Gray \& Torben Pedersen: Decision Factors Influencing MNEs Regional Headquarters Location Selection Strategies

2006-13 Peter Maskell, Torben Pedersen, Bent Petersen \& Jens Dick-Nielsen: Learning Paths to Offshore Outsourcing - From Cost Reduction to Knowledge Seeking

2006-14 Christian Geisler Asmussen: Local, Regional or Global? Quantifying MNC Geographic Scope

2006-15 Christian Bjørnskov \& Nicolai J. Foss: Economic Freedom and Entrepreneurial Activity: Some Cross-Country Evidence

2006-16 Nicolai J. Foss \& Giampaolo Garzarelli: Institutions as Knowledge Capital: Ludwig M. Lachmann's Interpretative Institutionalism

2006-17 Koen H. Heimriks \& Jeffrey J. Reuer: How to Build Alliance Capabilities

2006-18 Nicolai J. Foss, Peter G. Klein, Yasemin Y. Kor \& Joseph T. Mahoney: Entrepreneurship, Subjectivism, and the Resource - Based View: Towards a New Synthesis

2006-19 Steven Globerman \& Bo B. Nielsen: Equity Versus Non-Equity International Strategic Alliances: The Role of Host Country Governance

\section{7}

2007-1 Peter Abell, Teppo Felin \& Nicolai J. Foss: Building Micro-Foundations for the Routines, Capabilities, and Performance Links 
2007-2 Michael W. Hansen, Torben Pedersen \& Bent Petersen: MNC Strategies and Linkage Effects in Developing Countries

2007-3 Niron Hashai, Christian G. Asmussen, Gabriel R.G. Benito \& Bent Petersen: Predicting the Diversity of Foreign Entry Modes

2007-4 Peter D. Ørberg Jensen \& Torben Pedersen: Whether and What to Offshore?

2007-5 Ram Mudambi \& Torben Pedersen: Agency Theory and Resource Dependency Theory: Complementary Explanations for Subsidiary Power in Multinational Corporations

2007-6 Nicolai J. Foss: Strategic Belief Management

2007-7 Nicolai J. Foss: Theory of Science Perspectives on Strategic Management Research: Debates and a Novel View

2007-8 Dana B. Minbaeva: HRM Practices and Knowledge Transfer in MNCs

2007-9 Nicolai J. Foss: Knowledge Governance in a Dynamic Global Context: The Center for Strategic Management and Globalization at the Copenhagen Business School

2007-10 Paola Gritti \& Nicolai J. Foss: Customer Satisfaction and Competencies: An Econometric Study of an Italian Bank

2007-11 Nicolai J. Foss \& Peter G. Klein: Organizational Governance

2007-12 Torben Juul Andersen \& Bo Bernhard Nielsen: The Effective Ambidextrous Organization: A Model of Integrative Strategy Making Processes.

\section{8}

2008-1 Kirsten Foss \& Nicolai J. Foss: Managerial Authority When Knowledge is Distributed: A Knowledge Governance Perspective

2008-2 Nicolai J. Foss: Human Capital and Transaction Cost Economics.

2008-3 Nicolai J. Foss \& Peter G. Klein: Entrepreneurship and Heterogeneous Capital.

2008-4 Nicolai J. Foss \& Peter G. Klein: The Need for an Entrepreneurial Theory of the Firm.

2008-5 Nicolai J. Foss \& Peter G. Klein: Entrepreneurship: From Opportunity Discovery to Judgment.

2008-6 Mie Harder: How do Rewards and Management Styles Influence the Motivation to Share Knowledge?

2008-7 Bent Petersen, Lawrence S. Welch \& Gabriel R.G. Benito: Managing the Internalisation Process - A Theoretical Perspective.

2008-8 Torben Juul Andersen: Multinational Performance and Risk Management Effects: Capital Structure Contingencies. 
2008-9 Bo Bernard Nielsen: Strategic Fit and the Role of Contractual and Procedural Governance in Alliances: A Dynamic Perspective.

2008-10 Line Gry Knudsen \& Bo Bernhard Nielsen: Collaborative Capability in R\&D Alliances: Exploring the Link between Organizational and Individual level Factors.

2008-11 Torben Juul Andersen \& Mahesh P. Joshi: Strategic Orientations of Internationalizing Firms: A Comparative Analysis of Firms Operating in Technology Intensive and Common Goods Industries.

2008-12 Dana Minbaeva: HRM Practices Affecting Extrinsic and Intrinsic Motivation of Knowledge Receivers and their Effect on Intra-MNC Knowledge Transfer.

2008-13 Steen E. Navrbjerg \& Dana Minbaeva: HRM and IR in Multinational Corporations: Uneasy Bedfellows?

2008-14 Kirsten Foss \& Nicolai J. Foss: Hayekian Knowledge Problems in Organizational Theory.

2008-15 Torben Juul Andersen: Multinational Performance Relationships and Industry Context.

2008-16 Larissa Rabbiosi: The Impact of Subsidiary Autonomy on MNE Knowledge Transfer: Resolving the Debate.

2008-17 Line Gry Knudsen \& Bo Bernhard Nielsen: Organizational and Individual Level Antecedents of Procedural Governance in Knowledge Sharing Alliances.

2008-18 Kirsten Foss \& Nicolai J. Foss: Understanding Opportunity Discovery and Sustainable Advantage: The Role of Transaction Costs and Property Rights.

2008-19 Teppo Felin \& Nicolai J. Foss: Social Reality, The Boundaries of Self-fulfilling Prophecy, and Economics.

2008-20 Yves Dos, Nicolai J. Foss \& José Santos: A Knowledge System Approach to the Multinational Company: Conceptual Grounding and Implications for Research

2008-21 Sabina Nielsen \& Bo Bernhard Nielsen: Why do Firms Employ foreigners on Their Top Management Teams? A Multi-Level Exploration of Individual and Firm Level Antecedents

2008-22 Nicolai J. Foss: Review of Anders Christian Hansen's “Uden for hovedstrømmen - Alternative strømninger i økonomisk teori"

2008-23 Nicolai J. Foss: Knowledge, Economic Organization, and Property Rights

2008-24 Sjoerd Beugelsdijk, Torben Pedersen \& Bent Petersen: Is There a Trend Towards Global Value Chain Specialization? - An Examination of Cross Border Sales of US Foreign Affiliates 
2008-25 Vikas Kumar, Torben Pedersen \& Alessandro Zattoni: The performance of business group firms during institutional transition: A longtitudinal study of Indian firms

2008-26 Sabina Nielsen \& Bo B. Nielsen: The effects of TMT and Board Nationality Diversity and Compensation on Firm Performance

2008-27 Bo B. Nielsen \& Sabina Nielsen: International Diversification Strategy and Firm Performance: A Multi-Level Analysis of Firm and Home Country Effects

\section{9}

2009-1 Nicolai J. Foss: Alternative Research Strategies in the Knowledge Movement: From Macro Bias to Micro-Foundations and Multi-Level Explanation

2009-2 Nicolai J. Foss \& Peter G. Klein: Entrepreneurial Alertness and Opportunity Discovery: Origins, Attributes, Critique

2009-3 Nicolai J. Foss \& Dana B. Minbaeva: Governing Knowledge: The Strategic Human Resource Management Dimension

2009-4 Nils Stieglitz \& Nicolai J. Foss: Opportunities and New Business Models: Transaction Cost and Property Rights Perspectives on Entrepreneurships

2009-5 Torben Pedersen: Vestas Wind Systems A/S: Exploiting Global R\&D Synergies

2009-6 Rajshree Agarwal, Jay B. Barney, Nicolai J. Foss \& Peter G. Klein: Heterogeneous Resources and the Financial Crisis: Implications of Strategic Management Theory

2009-7 Jasper J. Hotho: A Measure of Comparative Institutional Distance

2009-8 Bo B. Nielsen \& Sabina Nielsen: The Impact of Top Management Team Nationality Diversity and International Experience on Foreign Entry Mode

2009-9 Teppo Felin \& Nicolai Juul Foss: Experience and Repetition as Antecedents of Organizational Routines and Capabilities: A Critique of Behaviorist and Empiricist Approaches

2009-10 Henk W. Volberda, Nicolai J. Foss \& Marjorie E. Lyles: Absorbing the Concept of Absorptive Capacity: How To Realize Its Potential in the Organization Field

2009-11 Jan Stentoft Arlbjørn, Brian Vejrum Wæhrens, John Johansen \& Torben Pedersen: Produktion i Danmark eller offshoring/outsourcing: Ledelsesmæssige udfordringer 


\section{0}

2010-1 Dana B. Minbaeva, Kristiina Mäkelä \& Larissa Rabbiosi: Explaining Intraorganizational Knowledge Transfer at the Individual Level

2010-2 Dana B.Minbaeva \& Torben Pedersen: Governing Individual Knowledge Sharing Behavior

2010-3 Nicolai J. Foss \& Peter G. Klein: Alertness, Judgment, and the Antecedents of Entrepreneurship

2010-4 Nicolai J.Foss \& Joseph T.Mahoney: Exploring Knowledge Governance

2010-5 Jasper J. Hotho, Florian Becker-Ritterspach \& Ayse Saka-Helmhout: Enriching Absorptive Capacity Through Social Interaction

2010-6 Nicolai J. Foss \& Bo B. Nielsen: Researching Collaborative Advantage: Some Conceptual and Multi-level Issues

2010-7 Nicolai J. Foss \& Nils Stieglitz: Modern Resource-Based Theory(ies) 